\title{
GEOTHERMAL GUIDEBOOK
}

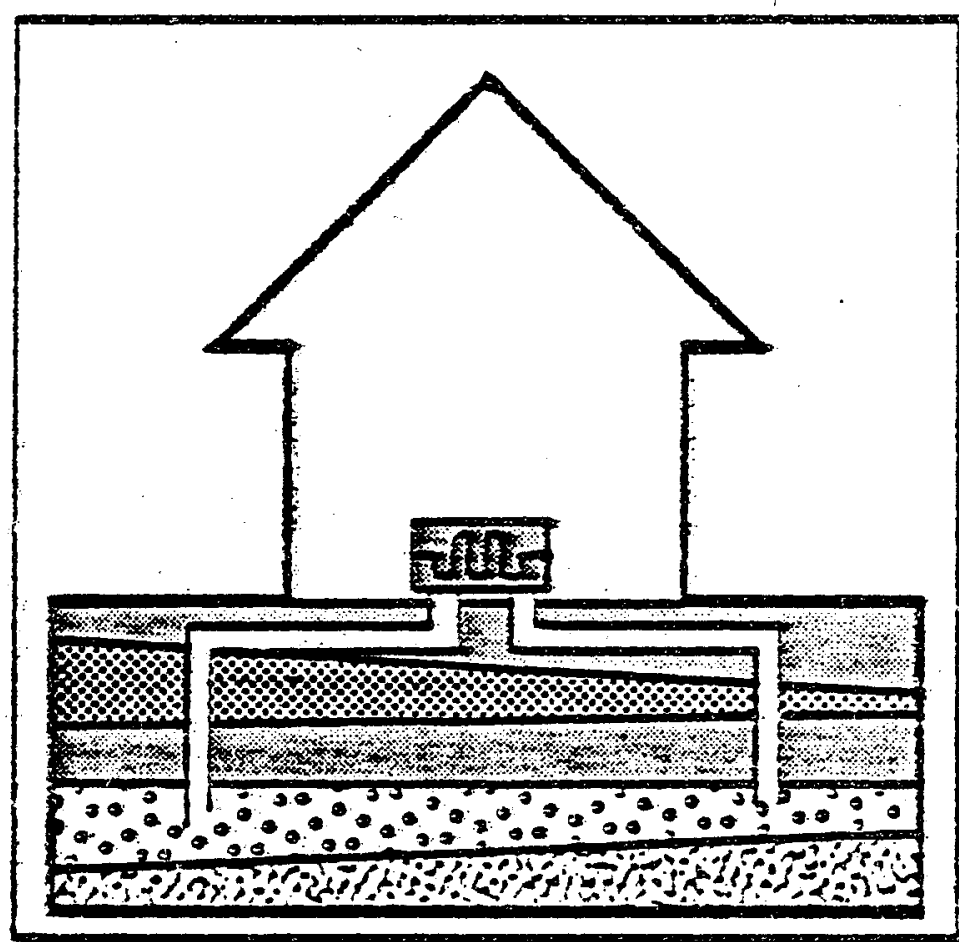

\section{June 1981 \\ NOTICE}

PORTIONS OF THIS REPORT ARE ILLEGIBLE. It

has been reproduced from the best available copy to permit the broadest possible avail. ability.

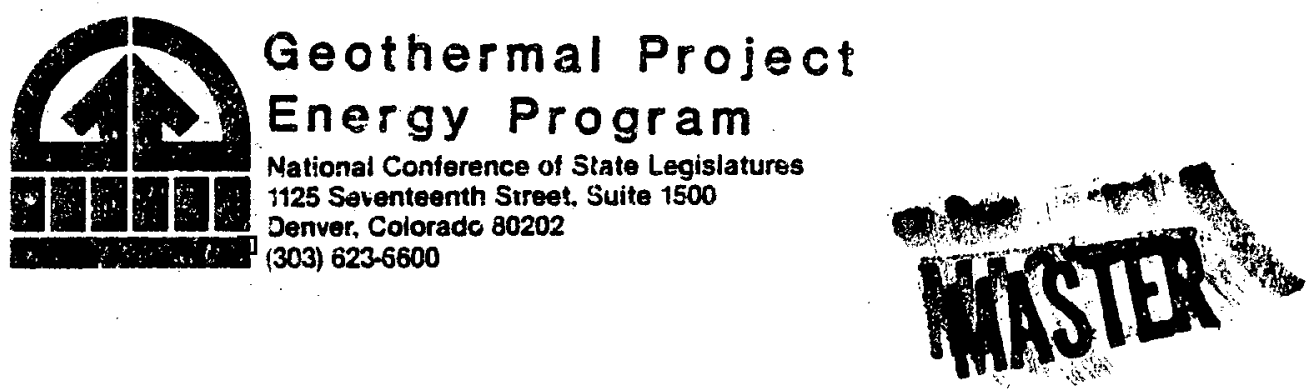




\section{DISCLAIMER}

This report was prepared as an account of work sponsored by an agency of the United States Government. Neither the United States Government nor any agency Thereof, nor any of their employees, makes any warranty, express or implied, or assumes any legal liability or responsibility for the accuracy, completeness, or usefulness of any information, apparatus, product, or process disclosed, or represents that its use would not infringe privately owned rights. Reference herein to any specific commercial product, process, or service by trade name, trademark, manufacturer, or otherwise does not necessarily constitute or imply its endorsement, recommendation, or favoring by the United States Government or any agency thereof. The views and opinions of authors expressed herein do not necessarily state or reflect those of the United States Government or any agency thereof. 


\section{DISCLAIMER}

Portions of this document may be illegible in electronic image products. Images are produced from the best available original document. 
I. OVERVIEW $\ldots \ldots \ldots \ldots \ldots \ldots \ldots \ldots \ldots \ldots \ldots \ldots \ldots \ldots \ldots \ldots \ldots \ldots \ldots \ldots \ldots \ldots \ldots$

Why Geotherma $]$ Energy? .................................... I

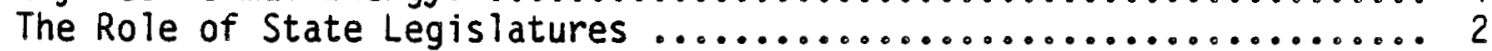

The Role of NCSL .................................... 3

II. THE GEOTHERMAL RESOURCE $\ldots \ldots \ldots \ldots \ldots \ldots \ldots \ldots \ldots \ldots \ldots \ldots \ldots \ldots \ldots \ldots$

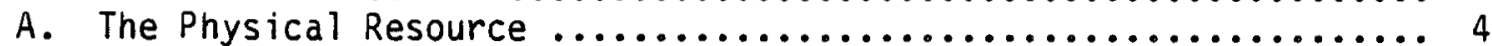

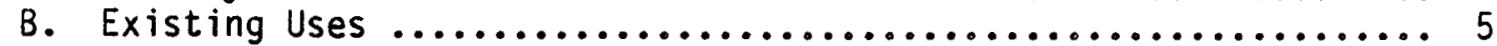

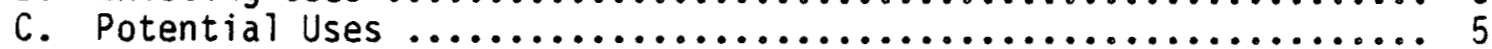

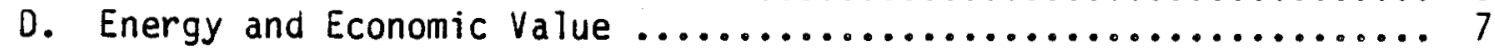

III. STATUTES AND REGULATIONS $\ldots \ldots \ldots \ldots \ldots \ldots \ldots \ldots \ldots \ldots \ldots \ldots \ldots \ldots \ldots \ldots \ldots$

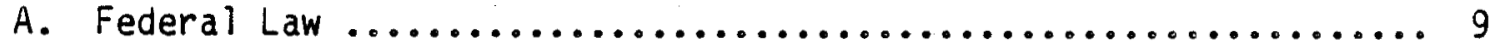

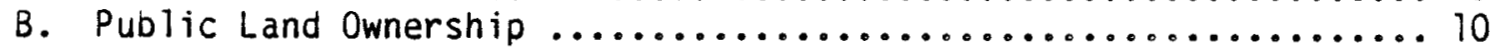

C. State Statutes ...................................

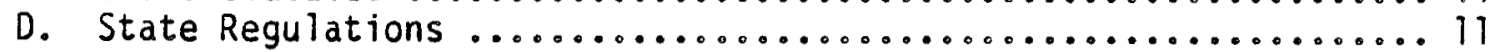

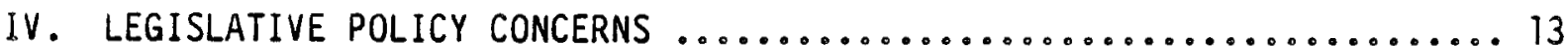

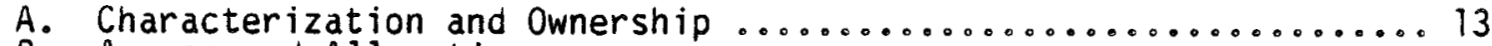

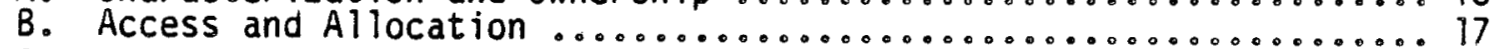

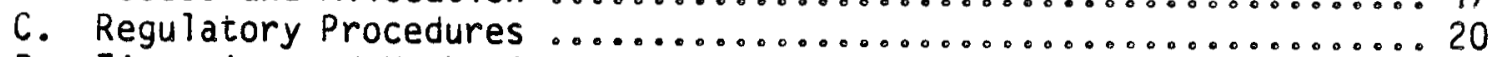

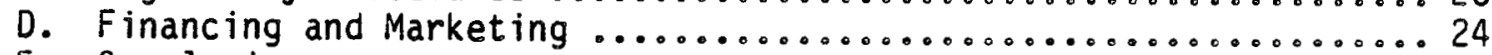

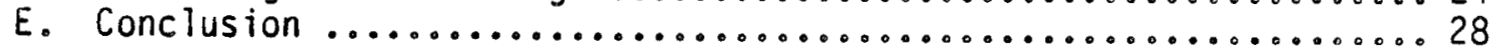

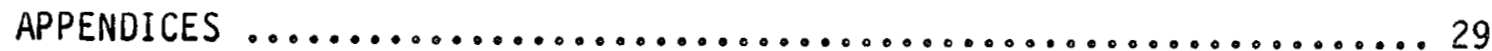

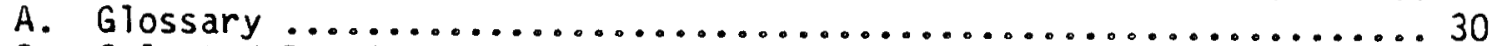

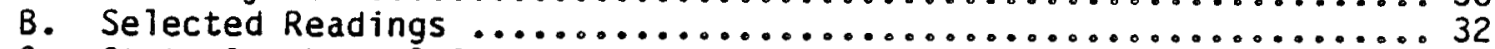

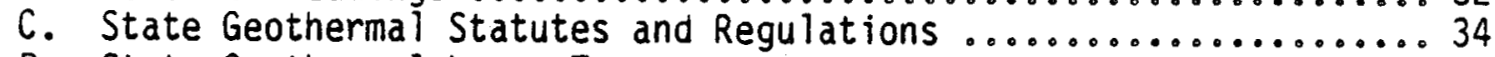

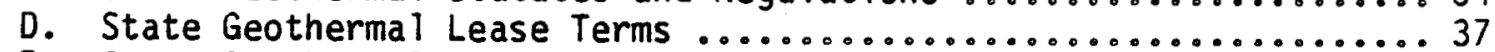

E. State Geothermal Incentives ............................. 4 1

F. District Heating Article .......................... 47

\section{DISCLAIMER}

This report was prepared as an account of work sponsored by an agency of the United States Government. Neither the United States Government nor any agency thereof, nor any of their employees, makes any warranty, express or implied, or assumes any legal liability or responsibility for the accuracy, completeness, or usefulness of any information, apparatus, product, or process disclosed, or represents that its use would not infringe privately owned rights. Reference herein to any specific commercial product, process, or service by trade name, trademark, manufacturer, or otherwise does not necessarily constitute or imply its endorsement, recommendation, or favoring by the United States Government or any agency thereof. The views and opinions of authors expressed herein do not necessarily state or reflect those of the United States Government or any agency thereof. 
PART I -- OVERVIEW

Why Geothermal Energy?

Energy supply is one of the most important questions facing state legislatures today. The question of how each state can ensure the reliability and sufficiency of its future energy supplies in a manner which is economically viable, environmentally acceptable and politically feasible is receiving a great deal of attention in the nation's statehouses.

The United States currently imports almost half of its oil--nearly one-quarter of the total energy demand. The concerns raised by this heavy reliance on an increasingly expensive resource in an unstable and politically explosive world market come at a time of dwindling reserves of natural gas, environmental problems with coal and difficulties with nuclear power.

Renewable energy resources are being given increasing attention and support in all parts of the country. Solar, wind, small-scale hydropower and geothermal energy all rely on indigenous resources. They are cleaner and safer than conventional energy sources and do not depend on a finite and limited resource base--such as petroleum. And, perhaps most important, once a facility has been constructed, the costs thereafter are minimal.

Geothermal energy--the heat of the earth--can be used either directly (as steam or hot water) or indirectly (to generate electricity). Currently the United States uses both forms: over 900 megawatts of electricity (Mwe) are generated at The Geysers power plant in California, and many areas heat homes, buildings, greenhouses and industrial process water with geothermal energy. Yet, the potential is far greater. The U.S. Geological Survey (USGS) estimates that identified geothermal resources can generate 23,000 Mwe over a thirty-year period and also yield approximately forty-two 
quads of direct heat.* The USGS estimates further that undiscovered geothermal resources represent over five times the energy of the identified resources. Although the USGS has not looked at the costs of developing this energy, numerous studies indicate that this energy source holds great costcompetitive promise.

The Role of State Legislatures

Geothermal development largely depends on public and private investment in this relatively untried resource. State policies, however, play a prominent role, both in the regulation of geothermal development and in promoting its use. Legislative concerns fall into four main categories:

A. Characterization and Ownership

What are geothermal resources and how do they relate to other resource categories, especially water?

Who controls geothermal property rights?

B. Access and Allocation

How can geothermal development rights on public lands be obtained?

How shall competing producers share a common supply?

C. Regulatory Procedures

Are there adequate controls on geothermal development?

Is the regulatory system simple and efficient?

D. Financing and Marketing

How may investment in geothermal development be encouraged?

How may geothermal markets be expanded?

Many geothermal policy areas were developed with regard to other resources, or before the need for geothermal energy was realized. Legislatures may find worthwhile a comprehensive review of all state policies which affect the production, costs and use of geothermal energy.

*One quad is the energy equivalent of 175 million barrels of oil; forty-two quads represents 54 percent of total U.S. energy use. 
The Role of NCSL

The National Conference of State Legislatures (NCSL) is the official representative of the nation's 7,500 state legislators and their staffs. NCSL is funded by the states and governed by a 43-member Executive Committee. The NCSL headquarters are in Denver, Colorado, with an Office of State-Federal Relations located in Washington, D.C.

Executive Director: Earl S. Mackey

The National Conference of State Legislatures has three basic objectives:

- To improve the quality and effectiveness of state legislatures;

- To assure states a strong, cohesive voice in the federal decision-making process; and

- To foster interstate communication and cooperation.

The principal objective of the NCSL Geothermal Project is to stimulate and assist state legislative action to encourage the efficient development of geothermal resources, including use of groundwater heat pumps. Project activities include:

- state geothermal policy reviews

- technical assistance

- liaison with geothermal community

- project evaluation.

The Geothermal Project has provided technical assistance to 17 states. 
PART II -- THE GEOTHERMAL RESOURCE

A. THE PHYSICAL RESOURCE

Every point of the globe rests on an ocean of molten rock at $1000^{\circ} \mathrm{C}$ (about $1800^{\circ} \mathrm{F}$ ). This tremendous source of heat surfaces most dramatically as geysers, hot springs and volcanoes. It is, however, more prevalent than just in these displays: broad belts of accessible geothermal energy encircle the earth. This energy frequently heats large subsurface rock formations (known as hot dry rocks) or creates underground reservoirs of steam and hot water (known as hydrothermal convection systems).

Hydrothermal convection systems vary. Vapor-dominated systems such as The Geysers in California consist solely of dry steam hotter than $240^{\circ} \mathrm{C}$ $\left(464^{\circ} \mathrm{F}\right)$. Liquid-dominated systems contain a mixture of steam and very hot water; they have a broad temperature range and generally are divided into high, medium and low temperature categories. Geopressurized thermal resources have a medium temperature, but very high pressure and large amounts of dissolved natural gas increase their energy content. Most plentiful are the low-temperature hydrothermal convection systems--under $90^{\circ} \mathrm{C}\left(194^{\circ} \mathrm{F}\right)$.offering great potential for small-scale uses.

In the United States the thirteen western states (including Alaska and Hawaii) contain the highest-temperature, most promising geothermal resources. The U.S. Geological Survey has identified three vapor-dominated systems, fifty-two high temperature liquid-dominated systems (between $150^{\circ} \mathrm{C}$ and $240^{\circ} \mathrm{C}$ ), and 163 medium temperature liquid-dominated systems (between $90^{\circ}$ and $\left.150^{\circ} \mathrm{C}\right)--\mathrm{all}$ in the West. Most geopressurized systems, however, are found in the Gulf states. Low-temperature systems are found in the west, the Gulf states and the Appalachian Mountain states from Georgia to Massachusetts. 
Location of Geothermal Resources in the United States.

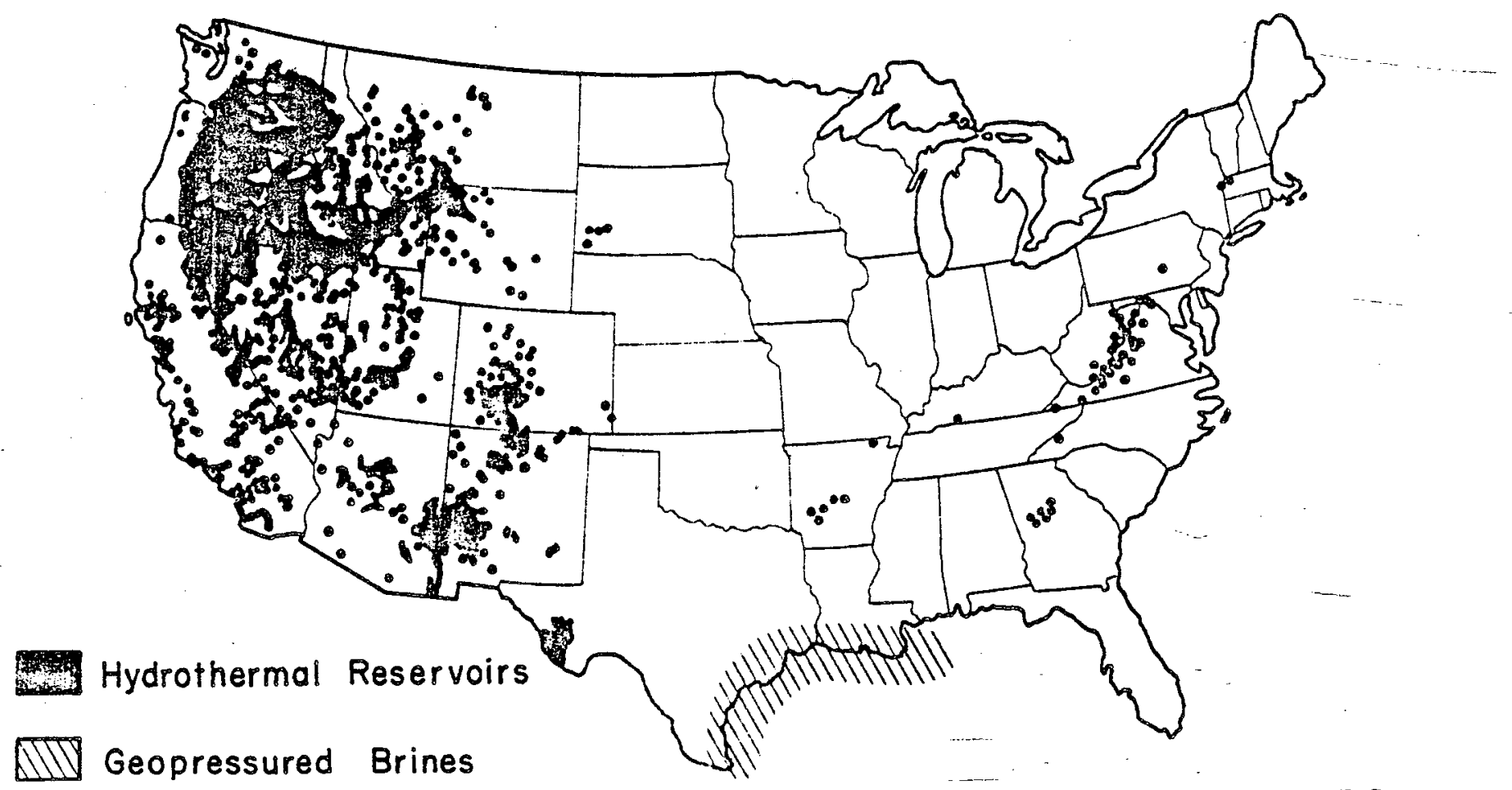

Source: Department of the Interior. "Final Envirommental Stalemw'nt ior hhe Gecthermal Leasing Office." Washington, D.C.: Government Printing Office, 1973. Vol. 1, p. II-17. 
The USGS has classified more than 3 million acres in 108 promising locations as "Known Geothermal Resource Areas". It has classified an additional 100 million acres as Prospective Geothermal Resource Areas.

At least twenty-eight states have some form of prospectively available hydrothermal convection system. Furthermore, all fifty states can efficiently use the heat contained in normal groundwater. In short, the natural energy of the earth represents a resource which can be used in all regions of the country.

\section{B. EXISTING USES}

Geothermal energy has a long history of direct use in the United States and around the world. Hot springs were used by American Indians for bathing and for scalding wild fowl; pioneers used them for drinking, bathing and watering stock; the therapeutic use of hot springs in spas (balneology) is well known. Modern uses of geothermal heat in the U.S. are widespread and include residential and commercial space heating, food dehydration and processing, warm-water irrigation and greenhouse heating, "pre-heated" industrial process waters, aquaculture, snow melting, car washing, explosives manufacture, dry ice production, and other specific applications.

At present The Geysers is the only power plant that relies on geothermal energy for electricity production. It has a current capacity of 908 megawatts--enough electricity to meet the needs of nearly one million people-- and is scheduled to eventually generate more than 1,500 megawatts. Power plants are currently under development in Utah, Idaho, New Mexico, Nevada, and California's Imperial Valley.

\section{POTENTIAL USES}

All of the above ongoing uses of geothermal resources demonstrate their viability as an energy source. Many areas which already utilize the 
resource can expand to other uses. Areas which do not yet tap geothermal resources may find the economics encouraging.

In addition to the proven uses already mentioned there are many other prospective applications, such as residential cooling, crop and timber drying, in pulp and paper mills, and ethanol distillation for use in gasohol. Furthermore, the energy and economic efficiency of geothermal utilization can be increased by "cascading"--using industrially discharged water in space heating, for example. Figure 1 charts the temperatures ranges needed by various industrial processes. These temperatures are typical for low-tomedium temperature geothermal waters.

Current technologies require geothermal waters of at least $170^{\circ} \mathrm{C}\left(338^{\circ} \mathrm{F}\right)$ for electrical generation. Geothermal power plants are in the planning stages in Idaho, New Mexico and Nevada. Hot dry rocks are a potential source of electricity; however, that development must await technical advances.

Heat pumps also make use of natural energy supplies; they are reversible devices which move heat from one point to another, thereby heating one location and cooling the other. The advantage of heat pumps which uti $i$ ize groundwater, rather than the more common air-to-air system, is that ground. water stays at a fairly constant temperature--warmer than cold winter air and cooler than hot summer air. Recent experience has demonstrated that groundwater heat pumps are cost-competitive with traditional sources of heat。*

\section{ENERGY AND ECONOMIC VALUE}

Direct-heat applications at less than $250^{\circ} \mathrm{C}\left(482^{\circ} \mathrm{F}\right)$ account for 40 percent of the nation's total energy consumption. The aggressive development of geothermal resources can displace the consumption of costly fossil resources for many of these purposes. Geothermal energy is relatively benign environmentally, and is not subject to the spiraling costs of fossil fuels 


\section{Figure 1.}

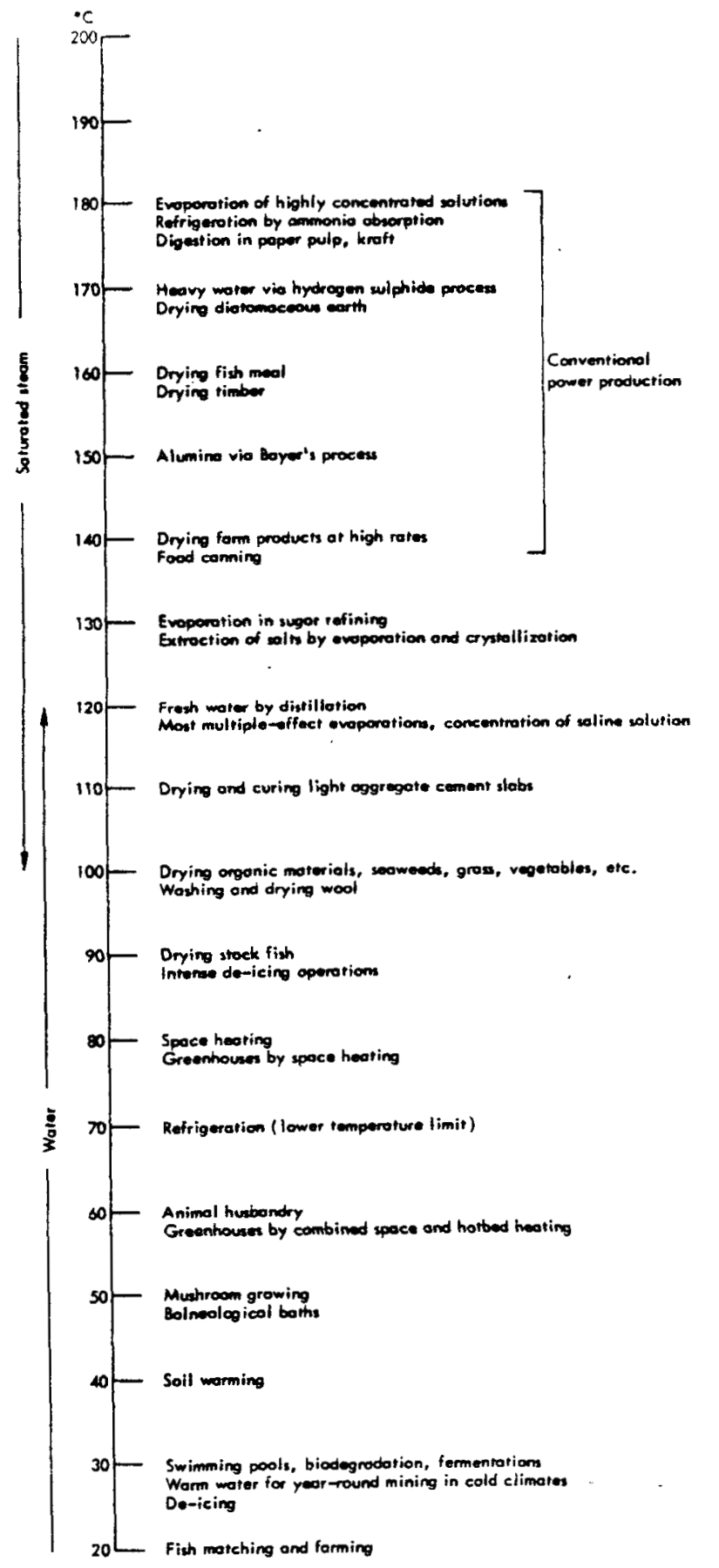

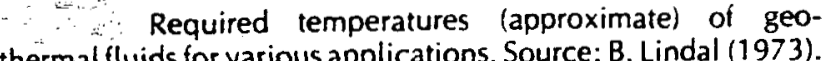


or their supply uncertainty. These fossil reserves may prove more valuable in the long term as chemical feedstocks rather than as heat sources.

Geothermal energy is most efficiently used near its production site. This factor, along with the diversity of end-uses it can meet, makes it particularly amenable to small-scale, locally determined energy needs. Geothermal utilization will not only promote a more diversified energy future for the nation, but will permit greater local participation in solving energy problems.

*For more information please see the Guidebook to Water-Source Heat Pumps, prepared by the Geothermal Project and available from NCSL. 


\section{Figure 2.}

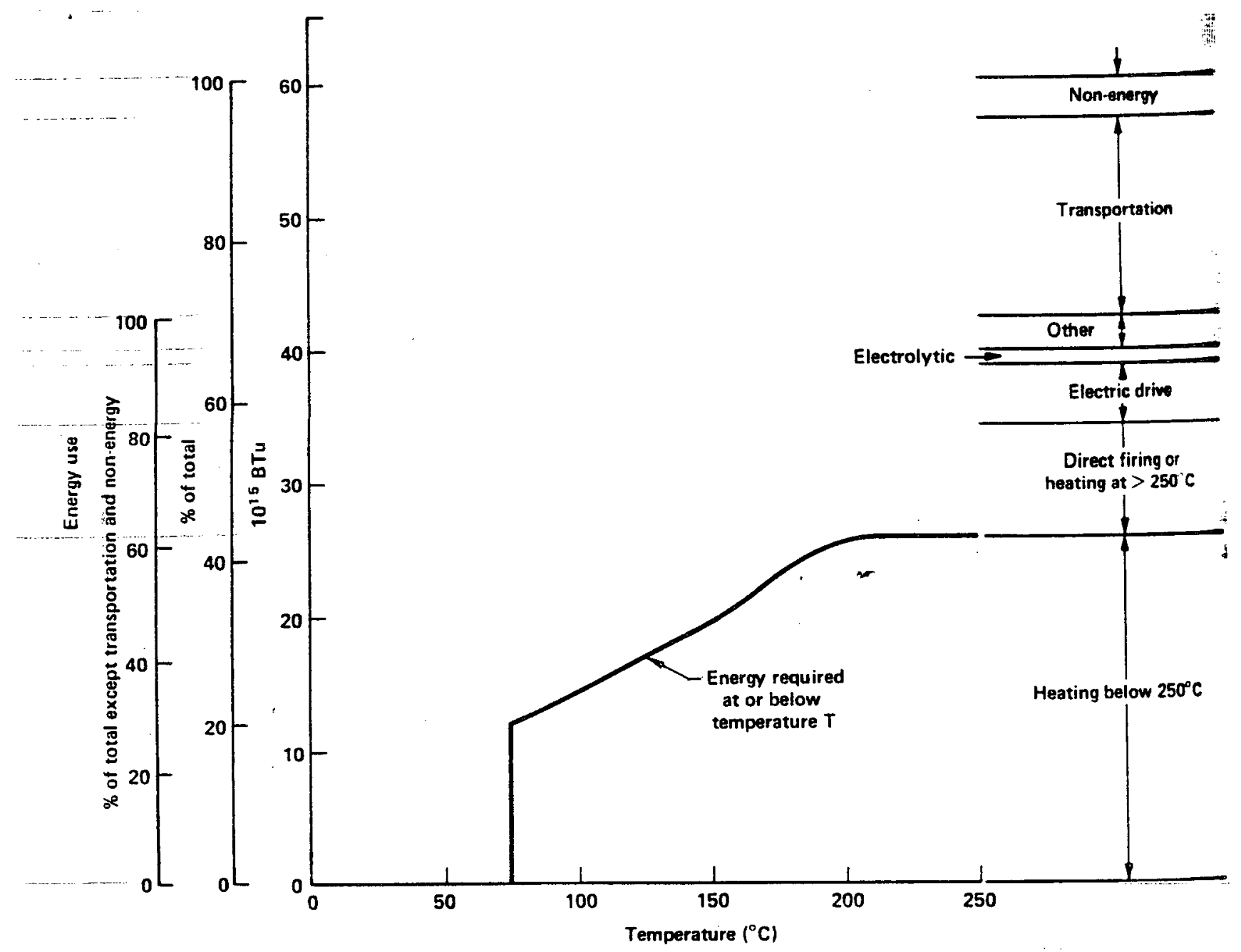

Cumulative energy use as a function of temperature of heat, shown in relation to the total energy requiremen in the United States in 1968 (Reistad, 1975a). Energy at $100^{\circ} \mathrm{C}$ or less will satisfy, in principle, $25 \%$ of the total enen use; at $160^{\circ}, 35 \%$ of the total. 
PART III -- STATUTES AND REGULATIONS

\section{A. FEDERAL LAW}

Various federal laws and policies affect geothermal development by establishing procedures for the use of federally owned geothermal resources, levying taxes and providing incentives. Particularly important are the Geothermal Steam Act of 1970 (30 U.S.C. 23, Secs. 1001-1025), the Geothermal Loan Guaranty Act (P.L. 93-410), and the comprehensive National Energy Act (P.L. 95-617 through 95-621). The key provisions of these acts and their corresponding regulations follow.

1. Geothermal Steam Act of 1970 (see also C.F.R. 270-271 and 43 C.F.R. 3000 et seq.).

a. The Secretary of the Interior may issue leases for the development of geothermal resources for all federally owned lands including mineral reservation lands.

b. Lands within Known Geothermal Resource Areas must be competitively leased; non-KGRA lands are non-competitively leased.

c. The Bureau of Land Management (BLM) conducts lease sales, contingent on the completion of Environmental Impact Statements (EISs) by the surface management agency.

d. National park, recreation and wilderness lands cannot be leased; tribal lands are under the jurisdiction of the Indian nations.

e. Lease size and terms, maximum holdings, and environmental requirements are specified.

The Federal Land Policy and Management Act of 1976 required that 50 percent of revenues received from federal geothermal leases would accrue directly to the state in which the leased lands are located.

2. Geothermal Loan Guaranty Act

The Geothermal Loan Guaranty Program (GLGP) was established in 1974. Its aim is to provide a federal guaranty--through the U.S. Department of 
Energy--of repayment of a commercially obtained loan in order to reduce the risks associated with geothermal development. To date the GLGP has guaranteed parts of five loans with several applications are pending.

3. National Energy Act

Two of the five acts within the National Energy Act are particularly important to geothermal energy.

a. "Energy Tax Act of 1978" (P.L. 95-618)

i. Authorizes the deduction of intangible drilling costs on the same basis as for oil and gas wells.

ii. Grants a declining depletion allowance for geothermal resources.

iii. Allows a residential energy tax credit for the use of geothermal energy.

iv. Establishes a supplemental business investment credit (not available to utilities) for equipment used to produce or use geothermal energy.

b. "Public Utility Regulatory Policies Act of 1978" (P.L. 95-617)

i. "Qualifying small power producers" (those that generate no more than 80 megawatts of electricity from renewable resources, which are presumed to include geothermal energy) can be interconnected to existing transmission facilities by order of the Federal Energy Regulatory Commission (FERC).

ii. FERC can require utilities to sell to or purchase electricity from small power producers.

iii. Power producers that generate no more than 30 megawatts may be exempted by FERC from the regulatory control of the Federal Power Act and state utility commissions.

\section{B. PUBLIC LAND OWNERSHIP}

The federal government is a major land holder in many states, particularly in the West. Federal land ownership in the West ranges from 9.7 percent of Hawaij's area to 95.3 percent of Alaska's. In these states federal decisions on the development of geothermal resources (and the restrictions 
placed by the Geothermal Steam Act of 1970) are of particular importance. In the non-western states the federal government controls no more than 9 percent of a given state's land, and generally much less. State land ownership in the West also varies greatly--from Hawaij's 36.4 percent to Nevada's 0.2 percent. In Arizona 44.6 percent of the 1 and is federally owned; 12.7 percent is state-owned.

\section{c. state statutes}

The past few years have seen numerous enactments related to geothermal resources and renewable energy. Some states have passed a broad spectrum of legislation ranging from the leasing of state geothermal lands to authorizing mechanisms for distribution of geothermally-heated waters. Other states nave just begun their policy reviews. For further information on state action, see appendices $C, D$ and $E$.

\section{STATE REguLATIONS}

As with state legislation, the status of geothermal regulation varies from state to state. Generally, the states which have promulgated regulations have established two sets; one relating to well drilling and the other to the leasing of state lands. Typical regulations follow:

1. Leasing regulations may distinguish between areas which are promising for electricity generation and those for direct uses; often they do not. Important features are:

- Method

- Primary Term

- Renewable Terms

- Renegotiation

- Annual Rental

- Royalties

- Acreage Limits

- Bonding Requirements 
2. Drilling regulations usually apply to all lands within the jurisdiction of the state. Frequently distinctions will be made between exploratory holes and producing wells. Main provisions are:

- Permitting

- Bonds

- Well Spacing

- Equipment

- Abandonment

- Unitization

- Environmental Safeguards 
PART IV -- LEGISLATIVE POLICY CONCERNS

Geothermal activity in the United States is in initial stages. Thus, the states may establish a comprehensive legal framework to guide the course of future development. For geothermal energy to reach its full potential, policies must be adopted that identify the resource, provide for prompt access and secure rights to the resource, and promote efficient regulatory procedures, equitable financial treatment and a substantial market. Geothermal developers favor legislative action on these issues because it reduces uncertainty regarding title to the resource, development methods, and obligations to competitors and the public interest.

A clear understanding of the nature of geothermal development is a prerequisite for effective legislation. Geothermal resources have distinctive characteristics that should be recognized in state laws and regulations. Regulatory experience with other resources is an important reference, but may not be transferable to geothermal development. Indeed, current state and federal geothermal policies are often criticized for excessive reliance on mineral or water law precedents. In addition, policies applied to deep, hot geothermal resources may be inappropriate for shallow, warm thermal fluids.

\section{A. CHARACTERIZATION AND OWNERSHIP}

The basic task is defining the geothermal resource and determining its relationship to other resource categories. This is a complex task due to the unique nature of geothermal resources which resemble in some respects water, minerals and gas. In addition, geothermal resources occur in a variety of geologic settings ranging from deep, hydrothermal reservoirs and hot dry rock strata to shallow aquifers in areas with a normal thermal gradient. 
Determination of the legal status of geothermal resources, including ownership and relationship to existing resource categories, has often been left to the judiciary. However, a legislative assignment has several advantages. Unlike courts, legislatures are not bound by precedent, nor are they limited to a particular factual dispute. Rather, they may examine a wide range of issues and make decisions on the basis of public policy.

\section{Characterization}

The basic element of value of a geothermal resource is heat (enthalpy), although some transfer medium, usually water, is a necessary component. In addition, valuable minerals and gases may be entrained or dissolved in the transfer medium. A complete definition would include all these physical constituents and help to avoid conflicting claims to separate components.

Deep, hot geothermal resources differ from shallow, warm groundwater in numerous ways. These differences include exploration and production methods, capital requirements, end uses, environmental impacts, and effects on standard water supplies. Definitions that utilize temperature and/or depth

thresholds or focus on end use attempt to recognize these differences. In general, deep, hot systems suitable for electrical generation or industrial process heat may properly be defined as unique or mineral resources, while shallow, warm systems suitable for residential, commercial and agricultural applications may properly be defined as groundwater.

Ownership

Defining a geothermal resource to be mineral or water may determine ownership as well. Mineral ownership derives from an estate in land, which may be severed from property rights to the overlying surface. Groundwater is generally held in the public domain in the western states but is considered an aspect of surface ownership in the eastern states.

The federal government claims geothermal ownership wherever it holds the mineral estate, either jointly with the surface estate or as a mineral reservation (severance). This claim was upheld in the Union 0il* case.

*see glossary for citation 
Whether federal ownership extends to groundwater that can be used for thermal purposes is unclear. In"the absence of an implied or explicit reservation of water pursuant to the establishment of a federal enclave, the states have primary control over water resources.

Two states (Oregon and Washington) have declared geothermal resources to be the property of the surface owner. The other states, either by statute or by practice, appear to recognize mineral ownership. In three states, Nevada, Utah and Wyoming, however, geothermal resources are classified as water, so it may be argued that geothermal resources in these three states are in the public domain.

This legal tangle creates possibilities for conflict. Surface owners, holders of the mineral estate, and water rights applicants all may claim ownership of the same geothermal resources. This uncertainty and the likelihood of litigation are a severe hindrance to development, so legislative clarification of the geothermal property regime is a priority.

\section{Relationship to Water}

Geothermal development may affect standard water supplies in both production and disposal stages. Disposal impacts will be dealt with in a later section. Production effects involve interference with established water uses. Such interference is more likely to occur with the development of shallow systems for direct applications than with the development of deep systems for electrical/industrial purposes. Thus, in this area also, geothermal resources proper may be treated in a different fashion than hot groundwater.

Blanket application of water law--whether the appropriation (western) or riparian (eastern) doctrine--to geothermal resources has several disadvantages. Initially, it may allow conflicting ownership claims arising from mineral rights versus water rights. At the development stage, water law doctrines (priority, reasonable use) are not the most efficient method of allocating production (discussed below). And, especially in the water-short west, the requirement to appropriate may be impossible or prohibitively expensive. 
Water law has three basic purposes: to convey property rights to a particular user, to protect established users and to insure the public interest. With regard to geothermal resources--as distinguished from hot groundwater--only the purpose of protection is relevant. This can be achieved without the wholesale application of water law and its attendant implications regarding ownership. Several states (Alaska, Arizona, California, Idaho, Oregon and Washington) provide mechanisms for geothermal development to proceed when development does not interfere with prior water rights. Such mechanisms may require the geothermal developer to demonstrate non-interference or may create a rebuttable presumption in his favor.

Other approaches are possible as well. For example, geothermal developers may be required to obtain water rights only for the amount of "consumptive" fluid use--allowing a credit for reinjection. The legal principle of "developed water" may also be applied to geothermal development. That is, a geothermal developer would obtain water rights to his total fluid production, even in critical ground basins, if he tapped an otherwise unavailable new source of water. Another logical approach is to require the geothermal developer to obtain only those water rights necessary to offset interference effects. Hydrologic sophistication and tailored legal treatment are the keys in this area.

It should be noted that classification of geothermal resources may affect access methods and financial liabilities as well as ownership and allocation. Generally, mineral resources are leased and are subject to royalties and/or severance taxes. Geothermal electrical and industrial projects can usually support such financial liabilities and are usually developed by exploration companies familiar with leasing practices for minerals, $0 i l$ and gas.

On the other hand, water resources are generally available for the taking rather than leased. Surface access may be obtained through ownership or (in the West) through eminent domain. Further, water use usually does not incur royalty or severance tax liability. These features would be attractive to small-scale direct users. Thus, the differentiation of geothermal resources 
and groundwater has effects which extend into virtually all areas of project operation.

A final issue in this area is that of "byproduct water." Some states provide authority for an agency to compel the production of demineralized byproduct water from geothermal projects and subject it to appropriation for beneficial use. Such authority must be exercised with care, taking into account project economics and reservoir maintenance (reinjection) programs. Additionally, the original producer should have a preferential right to appropriate project effluent. The water rights of other appropriators should be conditioned on non-interference with required reinjection and subject to project shut-downs and termination. The simplest course is probably to avoid establishing a separate property regime for the effluent from geothermal projects, allowing the geothermal producer to market such byproduct water to subsequent users where feasible.

\section{B. ACCESS AND ALLOCATION}

Some system of leasing, selling, franchising or licensing development rights to geothermal resources must be established. The system should not place a time-consuming burden on development and must allow developers to secure their investment. In addition, a method of allocating production among competing developers of a common supply is needed. The method should ensure adequate returns on investment while preventing waste of the resource.

\section{Access}

Resource distribution on public lands is commonly handled through patents (hard rock minerals) and leases (oil and gas, coal, common minerals). Patents commit surface and resource ownership to developers. Leases provide for surface occupation and production rights while surface and resource ownership remains in public hands. The federal government and most states (excepting geothermal "appropriation" states) have adopted leasing as the preferred method of providing access to geothermal resources. 
A "two-tiered" leasing approach is commonly used. In areas of strong geologic indications or competitive interest, bidding on leases is competitive. In other less promising or unexplored areas, leases may be obtained by application. Some states issue exploration permits in advance of leases. To provide security for discovery expenses, these permits may be exclusive and convertible to a lease.

The first task for a state legislature is to establish or review methods for providing access. For competitive leasing, various bid factors include cash bonuses, royalties, profit shares, rentals and work commitments. Cash bonus bidding tends to favor large, well-capitalized companies, while profit-share bidding allows for greater participation by smaller entrepreneurs. On the other hand, cash bonuses provide state treasuries with set returns that can be refunded to localities to mitigate development impacts.

The second task is to establish lease terms that balance public and private interests. Public interests include fair return on resource value, efficient production, and protection of surface lands. Private interests include security of tenure, flexibility in development, and profitability. Relevant terms address lease duration, renewal, rentals, bonding, stipulations (work commitments, environmental conditions, covenants for surface restoration), royalties or profit shares, and renegotiation. (See Appendix D.)

Finally, the access regime should address the problems of fragmentation and monopolization of the resource. Many states have adopted acreage limits, setting minimum acreages for individual parcels and maximum acreages for both individual and total holdings. Establishing a maximum number of parcels or number of townships occupied is another option for limiting total holdings. Leases actually in commercial production may be exempted from the limitation on total holdings. Acreage limits should correspond to the needs of geothermal development. Minimum acreages that are too high may inhibit small-scale projects, and maximum acreages that are too low may impede exploration and prevent developers from securing their investments. 
For small-scale users of hot groundwater, the leasing system should be less cumbersome than for major geothermal projects. For instance, a simple surface use/commercial lease with minimal rentals would be appropriate in many cases. The lessee would obtain a water right to the thermal resource, a right that should probably revert to the state upon termination of the lease.

\section{Allocation}

Although the earth's internal thermal energy may be virtually inexhaustible, it takes time for that heat to build up locally into a useful concentration. In addition, the geothermal fluids containing and transmitting heat are limited and usually slow to recharge. Therefore, the geothermal resource often is a "wasting" resource that has limited useful life. Reservoir dynamics may produce drawdowns in some areas as production occurs in others, so the geothermal resource is also a "fugitive" resource.

- Other wasting and fugitive resources--0il and gas, for instance--are generally allocated by one of two methods: the rule of capture, or correlative rights. The rule of capture implies that whatever is reduced to possession becomes the property of the producer. However, it is difficult to reduce geothermal heat to possession because it cannot be stored or transported for a long distance. In addition, the rule of capture may lead to a wasteful "race to capture" the resource that can result in overdrilling and reservoir damage. The efficient use of geothermal resources requires more coordinated development than occurs under a rule of capture.

The trend in geothermal resource allocation has been to a system of correlative rights. That is, each producer obtains a pro rata share (based on considerations of acreage, productivity, etc.) of a reservoir and the reservoir as a whole is managed for optimal utilization. Correlative shares in a geothermal reservoir may be assigned by a state agency or implemented through cooperative development--unitization. Unitization usually requires a specified percentage of operators to agree to the unit operation.

The application of the appropriation doctrine to geothermal reservoirs would preclude either of these two methods. Appropriative water rights create "quantified priorities" incompatible with a system of correlative rights and 
its inherent flexibility and equitable apportionment. Appropriation probably is the relevant doctrine for users of hot groundwater, however, since the actions of these users are likely to affect standard water users with established priorities.

The other prevailing doctrine for allocating groundwater--reasonable use-presents difficulties to thermal utilization of this resource. Transportation of groundwater from a particular surface parcel is precluded under reasonable use if damage results to other users of the common supply. There is no recourse to priority. This limitation could severely impede smal1scale projects involving production on one parcel and use on another.

\section{REGULATORY PROCEDURES}

The states have a valid interest in ensuring that geothermal development takes place in a manner that protects public health and welfare, the environment and other resources, and is fiscally responsible. Drilling controls, reinjection, environmental controls, and land use issues need to be examined. Protection of scarce water resources represents a special concern. It also is vital that the regulatory burden on geothermal development not be excessive.

\section{Drilling Controls}

The primary purpose of drilling controls is to ensure the use of proper techniques and equipment in constructing geothermal wells. This will protect freshwater aquifers from infiltration of geothermal brines and protect geothermal reservoirs from damage by well blow-outs. Such controls generally cover drill pad siting, casing, cementing, logging, blow-out prevention, disposal of drilling muds and well cuttings, well venting, and abandonment. Bonds are often required to ensure compliance with the regulations.

Drilling controls may also encompass well-spacing and pooling orders or production limits. Well-spacing orders commonly prevent drilling adjacent to parcel boundaries, roads, and buildings. They may also impose a 
well-location grid on entire geothermal systems, thereby limiting the number of holes drilled into a reservoir. A well-spacing grid may prevent lessees of small, scattered parcels from drilling. If so, leases will be "pooled" with adjacent producing leases. Production limits are usually applied as a modification of the rule of capture.

Reinjection often receives special attention with regard to the protection of intervening freshwater aquifers and the premature cooling of geothermal reservoirs. Reinjection is generally the preferred method of geothermal effluent disposal and can also help maintain reservoir pressures and fluid levels. Recent federal regulations promulgated under the Safe Drinking water Act (40 C.F.R. 141) apparentiy require up to three monitoring wells around each reinjection well.

\section{Environmental Controls}

Air, water and noise pollution, as well as the possibility of subsidence and increased seismic activity, are the environmental concerns associated with geothermal development. Air pollution is primarily in the form of hydrogen sulfide $\left(\mathrm{H}_{2} \mathrm{~S}\right)$ and would be regulated through the State Implementation Plans required by the federal Clean Air Act. Specific standards for acceptable ambient levels of $\mathrm{H}_{2} \mathrm{~S}$ are under development in $\mathrm{California}$ and New Mexico. Promising technological advances have been made in controlling $\mathrm{H}_{2} \mathrm{~S}$ emissions from geothermal facilities.

Water poliution problems in addition to those created by drilling include siltation of surface waters when geothermal projects are under construction, surface disposal of geothermal effluent, and the leaching of geothermal fluids from evaporation ponds into freshwater aquifers. Siltation problems are probably covered by the Army Corps of Engineers' "dredge and fill" program (Section 404 of the Federal Water Pollution Control Act). Surface disposal of geothermal effluent would require an NPDES permit (Sec. 402 FWP(A), usually issued by a state agency. Problems relating to leaching are more difficult to assess and control, but would probably fall under state area-wide water pollution control plans (Sec. 201 FWPCA). 
Noise associate with geothermal projects arises from construction and drilling activities, and especially from well venting to clear obstructions from the drill-hole. Most states do not have applicable noise control statutes. Recent advances in well muffling technology have reduced the scope of the problem.

Subsidence due to geothermal fluid production may be a significant problem in some areas. The irrigation system in the Imperial Valley of California, for example, is very sensitive to subsidence. The mandatory reinjection of geothermal fluid appears to be the answer in such areas. A related issue is whether reinjection of geothermal effluents may induce seismic events. A deep waste injection well in Colorado did cause increased seismicity. Indications are that seismic events induced by reinjection are minor in intensity and may in fact provide a "relief valve" for crustal tensions.

Land Use Controls

Compatibility of geothermal development with multiple land uses is, of course, a significant environmental concern. Both federal and state programs deal with the issue of compatibility. Protection of hot springs and geysers like those in Yellowstone National Park is of particular importance. The preservation of archaeological and historic sites is another goal.

The siting of geothermal facilities, especially of power plants, will usually be under the jurisdiction of public utility commissions. Generally, compatibility with local land use plans is also required. Geothermal utilization must occur near the production site since geothermal energy cannot be transported by barrel or pipeline for significant distances. Thus, normal site selection criteria, particularly alternative site requirements, may need to be waived for or tailored to the special requirements of geothermal development.

Impact Assessment

Federal (NEPA) and state (SEPA) environmental impact assessments may be triggered by the decision to issue a geothermal lease or exploration permit. These assessments can act as major stumbling blocks to rapid 
well-location grid on entire geothermal systems, thereby limiting the number of holes drilled into a reservoir. A well-spacing grid may prevent lessees of small, scattered parcels from drilling. If so, leases will be "pooled" with adjacent producing leases. Production limits are usually applied as a modification of the rule of capture.

Reinjection often receives special attention with regard to the protection of intervening freshwater aquifers and the premature cooling of geothermal reservoirs. Reinjection is generally the preferred method of geothermal effluent disposal and can also help maintain reservoir pressures and fluid levels. Recent federal regulations promulgated under the Safe Drinking Water Act (40 C.F.R. 141) apparently require up to three monitoring wells around each reinjection well.

Environmental Controls

Air, water and noise pollution, as well as the possibility of subsidence and increased seismic activity, are the environmental concerns associated with geothermal development. Air pollution is primarily in the form of hydrogen sulfide $\left(\mathrm{H}_{2} \mathrm{~S}\right)$ and would be regulated through the State Implementation $P$ lans required by the federal Clean Air Act. Specific standards for acceptable ambient levels of $\mathrm{H}_{2} \mathrm{~S}$ are under development in California and New Mexico. Promising technological advances have been made in controlling $\mathrm{H}_{2} \mathrm{~S}$ emissions from geothermal facilities.

Water pollution problems in addition to those created by drilling include siltation of surface waters when geothermal projects are under construction, surface disposal of geothermal effluent, and the leaching of geothermal fluids from evaporation ponds into freshwater aquifers. Siltation problems are probably covered by the Army Corps of Engineers' "dredge and fill" program (Section 404 of the Federal water Pollution Control Act). Surface disposal of geothermal effluent would require an NPDES permit (Sec. 402 FWP(A), usually issued by a state agency. Problems relating to leaching are more difficult to assess and control, but would probably fall under state area-wide water pollution control plans (Sec. 201 FWPCA). 
Noise associate with geothermal projects arises from construction and drilling activities, and especially from well venting to clear obstructions from the drill-hole. Most states do not have applicable noise control statutes. Recent advances in well muffling technology have reduced the scope of the problem.

Subsidence due to geothermal fluid production may be a significant problem in some areas. The irrigation system in the Imperial Valley of California, for example, is very sensitive to subsidence. The mandatory reinjection of geothermal fluid appears to be the answer in such areas. A related issue is whether reinjection of geothermal effluents may induce seismic events. A deep waste injection well in Colorado did cause increased seismicity. Indications are that seismic events induced by reinjection are minor in intensity and may in fact provide a "relief valve" for crustal tensions.

Land Use Controls

Compatibility of geothermal development with multiple land uses is, of course, a significant environmental concern. Both federal and state programs deal with the issue of compatibility. Protection of hot springs and geysers like those in Yellowstone National Park is of particular importance. The preservation of archaeological and historic sites is another goal.

The siting of geothermal facilities, especially of power plants, will usually be under the jurisdiction of public utility commissions. Generally, compatibility with local land use plans is also required. Geotherma] utilization must occur near the production site since geothermal energy cannot be transported by barrel or pipeline for significant distances. Thus, normal site selection criteria, particularly alternative site requirements, may need to be waived for or tailored to the special requirements of geothermal development.

Impact Assessment

Federal (NEPA) and state (SEPA) environmental impact assessments may be triggered by the decision to issue a geothermal lease or exploration permit. These assessments can act as major stumbling blocks to rapid 
geothermal development. Coordination of federal-state reviews should be sought. In addition, full-blown environmental assessments of total development impacts should be required only after a commercial discovery, with only an analysis of exploration impacts required prior to that time.

Regulatory Streamlining

In addition to coordinating state-federal environmental programs and distinguishing between exploration and development phases of a project, states may streamline their licensing procedures in other ways to minimize overlapping agency jurisdictions, eliminate redundant reviews, and shorten the time required to obtain environmental permits. Pre-application meetings between developers, regulators and public interest groups can often head off future problems. Imposing deadlines on agency decisions, such as California has done through its eighteen-month NOI/AFC process (Notice of Intent/Application for Certification) is another option.

Three other approaches to streamlining the decision process have been suggested. These include establishing a clearinghouse agency, a lead agency, or a single-stop agency.

Under a clearinghouse approach, one agency is granted authority to coordinate the entire application process between the applicant and all participating agencies. This agency does not have authority to overrule any permitting agency, but it does provide applicants with a single contact. The agency sends all applications to permitting agencies, receives decisions from those agencies, and forwards these decisions to the developer. It may also be given authority to enforce a licensing timetable.

A lead agency functions like a clearinghouse agency. In addition, it is granted appellate authority over other agencies in the decisionmaking process. If a developer and a subordinate agency cannot agree about a necessary license or permit, the lead agency acts as the arbiter.

A one-stop agency is staffed with experts in all the matters relating to applications and makes all decisions about applications. 


\section{FINANCE AND MARKETING}

Geothermal-development is a high-risk, capital intensive industry. Front-end expenses are large, and delays until commercial returns are realized are significant. This makes it vital that the financial treatment of the geothermal industry be at least equitable. In fact, incentives and subsidies for both geothermal producers and consumers may be desirable.

States may also take the initiative in marketing geothermal energy, through utility regulation. State legislatures should review the impact of public utility commission regulation of geothermal power generation, especially of geothermal direct applications. Other state actions, such as publicly funded demonstration projects, may also contribute to an expansion of the geothermal market.

Tax Incentives

Geothermal tax incentives may be considered for both producers and consumers. Federal incentives in this area have been outlined earlier. State incentives are described in Appendix $E$. Incentives for producers generally relate to the state income tax and the local property (ad valorem) tax. States may parallel federal tax benefits--additional investment credit, accelerated depreciation, deductions for intangible expenses, depletion allowance--in the ir income tax codes.

The ad valorem property tax is a particularly significant financial burden since it applies to front-end investment in geothermal equipment and facilities long before commercial returns are realized. Options to reduce this burden include exempting non-producing leases from property taxation or deferring payment of taxes until commercial returns are received. Alternatively, a wellhead tax (percentage of gross receipts) may be levied in lieu of an ad valorem tax.

Granting developers these benefits would, however, delay tax payments to the localities impacted by geothermal development. This problem may be alleviated in at least two ways. One approach would be to earmark a portion of 
state and federal geothermal lease revenues for return to impacted localities. Another would be to require geothermal developers to contract with impacted localities for services rendered before they qualify for tax benefits.

Income tax credits/deductions for consumers who buy geothermal equipment are a common incentive. An additional incentive would be to exempt from tax liability the value a geothermal installation adds to property. Sales tax exemptions are another possibility.

Other state taxes--severance tax, corporate franchise fee, sales tax, public utility tax--should also be reviewed for their impact on geothermal deve lopment.

\section{Loan Programs}

The federal Geothermal Loan Guaranty Program has been described earlier. States may also institute loan programs for renewable energy. For instance, Oregon provides low-interest loans to veterans who purchase renewable energy equipment for their homes. State loan programs may be funded by one-time or annual appropriations, or they may be set up as a revolving fund. The states may decide to authorize loans for residential, commercial and industrial applicants as well as for public projects.

\section{Public Finance}

Entities like municipalities, special districts, cooperatives, and industrial development authorities may wish to develop or use geothermal resources for power generation, heating districts or industrial parks. Their doing so raises legal questions relating to methods of forming utility/heating districts, service areas, and purposes and powers (especially financial). These questions are reviewed in Appendix $F$.

The two basic options public entities have for financing these activities are general obligation bonds and revenue bonds. General obligation bonds are supported by the faith and credit (taxing power) of the issuer and usually require a referendum. Interest rates are generally lower than rates 
for revenue bonds, but general obligation bonds are (except in the case of special districts) subject to constitutional/statutory debt limitations.

Revenue bonds are supported by project revenues (service charges, special assessments) rather than fully by the faith and credit of the issuer. For this reason they usually do not require a referendum and are not subject to debt limits. Since interest rates are usually higher on such bonds, however, states may wish to consider guaranteeing local bond issues as a means of obtaining lower interest rates. The most important factor in floating a revenue bond for a geothermal project is the power marketing contract obtained on the project.

A major problem with both these options is that they are inappropriate for funding feasibility studies, exploration, and other essential but high-risk initial phases of geothermal development. These phases require innovative approaches such as a state development fund or public sector/private sector joint ventures.

Other public finance options include direct appropriations, revolving loan funds, subordinated loans and leveraged leases. State securities commissions may be directed to rate geothermal revenue bonds as legal investments for institutional investors.

\section{Utility Markets}

Investor-owned utilities are traditionally conservative entities that may be reluctant to enter the geothermal field. Publicly owned utilities may be unable or unwilling to assume the risks inherent in this emerging technology. For these reasons, the usual development scenario begins when a geothermal exploration/production company markets its output to a utility, and the utility then converts this output to electricity. Development companies will not engage in these activities if they are subject to Public Utility Commission (PUC) jurisdiction over rates, accounts and organization.

Sometimes, however, geothermal developers may actually generate electrical power, for retail sale to selected customers or wholesale to a utility. In 
this situation, too, PUC jurisdiction operates as a disincentive. PURPA (discussed earlier) provides for exemptions from PUC jurisdiction in certain situations like these, but further action is the responsibility of the states. PURPA also provides for mandatory purchase by utilities of the output from "qualifying small power producers." Again, implementation is a state matter.

PURPA does not apply to "wheeling" the output of a qualifying small power producer across utility grids for retail sale, so this is an area for state initiative. The availability of wheeling may determine the feasibility of some projects, as when a geothermal producer wishes to wheel output to customers in an industrial park. One approach is to designate transmission lines as "common carriers" that can be used for a reasonable fee. The reliability of a grid and the impact of wheeling on a utility holding an exclusive franchise for a particular service area must be considered.

Utilities can be encouraged to participate in geothermal development in a number of ways. They may, for instance, be required to consider using renewable fuel sources for new capacity before turning to fossil or nuclear supplies. Allowing utilities to include the cost of construction work in progress in the rate base may act as an incentive to development. Utilities may be allowed a higher rate of return on equity invested in renewable facilities. They may also be authorized to recover their investment in geothermal projects that terminate because of the failure of a reservoir or a facility, although this option is likely to be controversial.

The direct use utility market can also be strengthened. Exemptions like those authorized by PURPA might be extended to geothermal heating districts. Heating districts could also be granted easements along or across transmission corridors and public byways. Eminent domain power may be necessary to complete the network.

\section{Market Expansion}

The states may foster the expansion of geothermal markets in a number of ways. Public education and technical assistance programs, administered by a 
geothermal ombudsman or the state energy office, can influence consumer acceptance of geothermal energy. Political subdivisions can benefit from planning and impact assistance. In particular, geothermal elements should be prepared for local zoning codes, since geothermal resources must be developed where they are found or not at all.

Building codes should also be examined for compatibility with geothermal equipment. Life-cycle costing of new or renovated public buildings should include analysis of the feasibility of using geothermal energy systems. State-funded demonstration projects can encourage geothermal acceptance. More radically, states may require that all new construction use geothermal energy where feasible, as San Diego County requires the use of solar hot water heaters.

\section{E. CONCLUSION}

Geothermal reserves are a major new energy resource. Domestic supplies are secure and environmental dangers are relatively minor. Innovative state legislation can provide a substantial impetus to geothermal development. Comprehensive policyies addressing all the areas discussed above and a step-by-step approach are both valuable. In any case, new policies should be monitored and revised as necessary to insure their effectiveness. 
APPENDICES

$-29$. 
APPENDIX A

$\underline{\text { Glossary }}$

Binary (heat exchange) system--electrical generating system in which geothermal energy heats a working fluid (with a low boiling point) to power turbines.

Byproducts--dissolved or entrained minerals and gases in geothermal fluids and extracted during production. (Statutory definitions generally exclude hydrocarbons.)

Cascading--the successive use of progressively cooler geothermal fluids for various direct applications.

Correlative rights--a legal principle that allocates a common supply among competing producers on the basis of equitable apportionment.

Developed water--a new source of water that a particular project development makes possible.

Direct use--the use of geothermal heat without conversion into electrical energy.

Enthalpy--heat content of a body or a system available as thermal energy.

Flash system--electrical-generating system in which high temperature geothermal fluids under pressure rapidly vaporize at atmospheric pressure to power turbines.

Geothermal--literally, "earth heat."

Groundwater heat pump--a device that uses groundwater as a heat source in the winter and as a heat sink in the summer.

Hot dry rock--geothermally heated rock that lacks a natural fluid for heat transfer.

Hydrothermal reservoir--a subsurface system containing geothermally heated fluids. If dry steam is produced (as at The Geysers in California), the reservoir is characterized as vapor-dominated; if steam and hot water are produced, the reservoir is liquid-dominated.

Industrial process water--water used for its chemical or heat value in industrial processes (e.g., hot water for food processing).

KGRA (Known Geothermal Resource Area)--lands classified by the USGS on the basis of geological and geophysical data, resource discoveries or overlapping lease applications. 
APPENDIX A (continued)

Material medium--substance used to transfer geothermal energy to the surface. It either occurs naturally (e.g., brine, steam) or is artificially injected (e.g., water, freon).

Mineral reservation--the severance of real property rights into separate surface and sub-surface (mineral) estates. The federal government claims ownership of geothermal resources where it has reserved the mineral rights, a claim upheld in the decision of Union 0il v. U.S., 369 FS 1289 (1973) rev'd. 549 F. 2d 1271 (1977) cert. den. 434 U.S. 930 (1978), reh. den. 435 U.S. 911 (1978).

Retrofitting--adapting facilities so they can use geothermal or other new energy sources.

Space conditioning--heating or cooling residential or commercial buildings for human comfort.

Sui generis--constituting a class alone; with unique properties.

Thermal gradient--rate of increase (or decrease) in temperature with distance below the surface; one indication of geothermal potential.

Unitization--cooperative development of a geothermal reservoir as agreed to by producers or required by the state.

${ }^{\circ} \mathrm{C}=5 / 9\left({ }^{\circ} \mathrm{F}-32\right)$

${ }^{O F}=9 / 5\left({ }^{\circ} \mathrm{C}\right)+32$ 
APPENDIX B

Selected Readings

Leading Articles

Elmer and Robers, "Legal Issues in the Development of Geopressured--Geothermal Resources of Texas and Louisiana Gulf Coast," PROCEEDINGS--SECOND GEOPRESSURED GEOTHERMAL ENERGY CONFERENCE, Vol. 5, i (1976).

0 lpin and Tarlock, "Water That Is Not Water," 13 LAND AND WATER L.R. (2) 391 (1978).

0lpin, Tarlock and Austin, "Geothermal Development and Western Water Law," UTAH LAW REVIEW (4) 773 (1979).

Sato and Crocker, "Property Rights to Geothermal Resources (1, 11)," 6 ECOLOGY L.Q. 250, 481 (1977).

U.S. Geological Survey, L.J.P. Muffler, Editor, CIRCULAR 790, (1978).

Vranesh and Musick, "Water and Other Conflicts Encountered by the Developer," 13 LAND AND WATER L.R. (1) 109 (1977).

\section{Additional References}

Aidlin, "United States Law as It Affects Geothermal Development," PROCEEDINGS--SECOND UNITED NATIONS SYMPOSIUM ON GEOTHERMAL RESOURCES, Vol. 3, p. 2353 (1975).

Allen, "Legal and Policy Aspects of Geothermal Resource Development," 8 WATER RESOURCES BULLETIN 250 (1973).

Beeland, et al., "Geothermal Development on Federal Lands--Impediments and Potential Solutions," WAPORA, INC. (January 1978).

Bible, "The Geothermal Steam Act of 1970," 8 IDAHO L.R. 86 (1972).

Bloomster, et al., "Geothermal Energy Potential for District and Process Heating AppTications in the U.S.--An Economic Analysis," BATTELLE

PACIFIC N.W. LAB (August 1977).

Bloomster, et al., "The Economics of Geothermal Electricity Generation from HydrothermaT Resources," BATTELLE.

Bjorge, "Development of Geothermal Resources and the 1970 Geothermal Steam Act--Law in Search of a Definition," 46 U. COLO. L.R. 1 (1974).

Davis, "Geothermal Resources for the Small Developer," 3 J. CONTEMPORARY LAW 241 (1977). 
APPENDIX B (continued)

EImer, FIRST ANNUAL REPORT OF THE GEOTHERMAL COMMITTEE OF THE ABA'S NATURAL RESOURCES SECTION.

Franzen, "Property Systems in Geothermal Resources: A Critique and Recommendations," PROCEEDINGS--SECOND UNITED NATIONS SYMPOSIUM ON GEOTHERMAL RESOURCES, Vol. 3, p. 2373 (1975).

Geothermal Resources Development Institute, THE ROCKY MOUNTAIN MINERAL LAW FOUNDATION (January 1977).

Geothermal Resources Development Institute, 13 LAND AND WATER REVIEW (1) UNIVERSITY OF WYOMING (1977).

Kitchen, "Geothermal: The Resource, the Law and the Landman," 22 ROCKY MOUNTAIN MINERAL LAW INSTITUTE 821 (1976)。

Nakamura, Nakahara and Iga, "Geothermal Rights and Problems of Legislation in Japan," PROCEEDINGS--SECOND UNITED NATIONS SYMPOSIUM ON GEOTHERMAL RESOURCES, Vol.3, p. 2421 (1975).

Schlauch and Worcester, "Geothermal Resources: A Primer for the Practitioner," 9 LAND AND WATER L.R. 327 (1974).

Torfason, "The Law of Iceland as It Affects Geothermal Development," PROCEEDINGS--SECOND UNITED NATIONS SYMPOSIUM ON GEOTHERMAL RESOURCES, Vol.3, P. 2435 (1975).

Wagner, "State Taxation of Geothermal Resources Compared with State Taxation of Other Energy Minerals (November 1977).

Weinstein, Gordon and Maslan, "Legal Aspects of Geothermal Energy Development," PROCEEDINGS--SECOND UNITED NATIONS SYMPOSIUM ON GEOTHERMAL RESOURCES, Vol. 3, p. 2447 (1975). 
APPENDIX C

State Laws and Regulations Regarding Geothermal Resources

ALASKA

Statutes: Geothermal Resources Act (1971); AK Stat. 38.05.181

Leasing: Div. of Lands - Regulations \& Statutes Pertaining to Coal and Other Leasable Minerals (1974) 11 A.A.C. $84.700 \ldots$

Drilling: Div. of 0il \& Gas - 11.A.A.C.94.730... (1974)

ARIZONA

Statutes: Geothermal Resources (1972); amend. HB 2257 (1979)

A.R.S. $27-651$

Leasing: Land Dept. - Geothermal Resources (1972) T.12C.5.A.22 (under revision)

Drilling: 0il \& Gas Conservation Comm. - General Rules \& Regulations Governing the Conservation of Geothermal Resources (1972) T.27C.4.A.4

CALIFORNIA

Statutes: leasing - Geothermal Resources Act (1967)

Pub. Res. Code 6902...

production - Laws for the Conservation of Geothermal

Resources (1967, as smend.) Pub. Res. Code 3700...

siting - Energy Resources Development; Conservation Act

(1974) Pub. Res. Code 25000...

Leasing: State Lands Comm. - Leases \& Prospecting Permits for Geothermal Resources (1970) C.A.C. 2250...

Drilling: Div. of $0 i 1$ \& Gas - Statewide Geothermal Regulations (1976) C.A.C. $1900 \ldots$

Siting: Energy Comm. - Provisions Applicable to Geothermal Notices \& Applications (1978)

COLORADO

Statutes: Geothermal Resources Act (1974) C.R.S. 34-70-101...

Leasing: Board of Land Commissioners - Special Rules and Regulations Relating to Geothermal Resources Leases (1972) SLB \#248-1

Drilling: 0 il \& Gas Conservation Comm. - Rules \& Regulations for the Development \& Production of Geothermal Resources (1976) G101...

HAWAII

Statutes: Government Mineral Rights (1974); amend. HB 3033 (1978)

H.R.S. 182-1...

Leasing: Dept. of Land \& Natural Resources - Regulations on Leasing \& Drilling Geothermal Resources (1978) Reg. No. 8

Drilling: Reg. No. 8

IDAHO

Statutes: leasing - Geothermal Resources Leasing Act (1975) 
APPENDIX C (continued)

ID Code $47-1601 \ldots$

IDAHO (continued)

production - Geothermal Resources Act (1974, as amend.)

ID Code $42-4001 \ldots$

Leasing: Board of Land Commissioners - Rules \& Regulations Governing

the Issuance of Geothermal Resources Leases (1974) (under revision)

Drilling: Water Resource Board - Drilling for Geothermal Resources (1978)

LOUISIANA

Statutes: Geothermal Energy Resources (1976) L.R.S. 30:800...;

Geothermal \& Geopressure Energy Research \& Development Act (1975) L.R.S. 30:681

Leasing: Mineral Board - none (oil \& gas model likely)

Drilling: Office of Conservation - statewide order 29-P (1978)

MARYLAND

Statutes: Geothermal Resources Act (1978) A.C.M. 8-8A-01

MONTANA

Statutes: leasing - Lease of Geothermal Resources (1974)

R.C.M. 81-2601...

siting - Major Facilities Siting Act (1975, as amend.)

R.C.M. 70-801...

filing bottom-hole temperatures - Act to Facilitate the

Discovery of Geothermal Energy Sources (1975)

R.C.M. 60-127, 144, 148

Leasing: Dept of State Lands - Geothermal Rules \& Regulations (1975)

M.A.C. $26-2.6(2)$

Drilling: Geological Survey - Conservation Division - Geothermal

Investigation Reports (1975) M.A.C. 36-2.8(14)

NEVADA

Statutes: leasing - An Act Relating to State Lands (1975)

N.R.S. $322.030 \ldots$

production - An Act Relating to Geothermal Resources (1975)

N.R.S. 534A.010

Leasing: Div. of Lands - pending

Drilling: Div. of Water Resources - Regulations Pertaining to

Exploration Drilling (1978)

NEW MEXICO

Statutes: Geothermal Resources Act (1967) N.M.S.A. 7-15-1...

Geothermal Resources Conservation Act (1975) (Chap.272)

Leasing: State Land Office - Rules \& Regulations Relating to Geothermal

Resources Leases (1971)

Drilling: 0il Conservation Div. - Rules \& Regulations for Geothermal Resources (1974) 
APPENDIX C (continued)

OREGON

Statutes: Geothermal Resources (1975) 0.R.S. 522.005... Geothermal Heating Districts (1975) 0.R.S. 523.010...

Leasing: Div. of State Lands - Geothermal Lease Regulations (T975) $75-010 \ldots$

Drilling: Dept. of Geology \& Mineral Industries - Rules, Regulations \& Laws Relating to Exploration \& Development of Geothermal Resources (1977) 632-20-005...

TEXAS

Statutes: Geothermal Resources Act (1975) V.A.C.S. Art. $5421 \mathrm{~s}$

Leasing: Railroad Comm./Div. of 0il \& Gas - none (0i) \& gas model likely)

Drilling: Railroad Comm./Div. of 0il \& Gas - Rules Having General Application to 0 il, Gas, \& Geothermal Resource Operations (1976) 051.02 .02 .000

School Land Board - RuTes \& Regulations Governing Drilling \& Producing on Permanent Free School Lands (1974) (general)

UTAH

Statutes: Water \& Irrigation Laws (1973) U.C.A. 73-1-120

Leasing: Div. of Lands - Rules \& Regulations Governing Issuance of Mineral Leases (1973); Geothermal Steam Lease Agreement (1973)

Drillin: Div. of Water Rights - Rules \& Regulations for Wells Used for the Discovery \& Production of Geothermal Energy (1978)

WASHINGTON

Statutes: Geothermal Resources Act (1974) T.79 R.C.W.

Leasing: Dept. of Natural Resources - Geothermal Leasing Policy (1978) DRAFT

Drilling: Dept. of Natural Resources - none

WYOMING

Statutes: Underground Water (1973) WY Stat. 41-121

Leasing: Board of Land Commissioners - Rules \& Regulations Governing the Issuance of Geothermal Resource Permits \& Leases (1975)

Drilling: State Engineer's Office--Rules \& Regulations 


\section{APPENDIX D}


Alaska

10 years

Arizona

10 years

California

20 years

Colorado

10 years

Hawaii

10 years

idaho

Louisiana

Montana

10 years

New Mexico

5 years*

Oregon

10 years

Texas

Utah

Wyoming one 5-year term if drilling; for duration of commercial production, up to 40 years

2 years if drilling; for duration of commercial production

so long as geothermal resources are produced or capable of being produced in commercial quantities, up to 99 years

for duration of commercial production; lacking production, at discretion of state land board

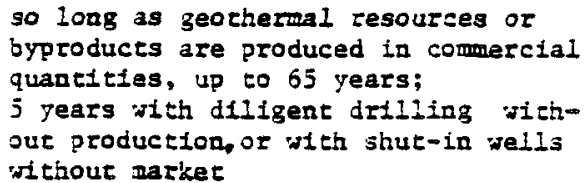

for duration of commercial production or drilling operations to at least $\mathbf{1 0 0 0}$ feet, up to $\mathbf{4 0}$ years beyond primary term

for duration of commercial production

or development operations

for duration of commercial production or drilling 20-year intervals beginning 35 years after commercial production; and at end of first 40-year lease period

10-year intervals, beginning 20 years after lease date

minimum royalty: 5-year intervals

15 year intervals, beginning 15 years aficer the lease date 10-year intervals, beginning 20 years after lease date so long as geothermal resources are produced or capable of being produced in comnercial quantities; "secondary 5-year term at incressed rental even without production. If praduction is lost subsequently, the commtssion may extend lease in one-year increments up to three years.

10 years, if royalties in any year of preceding term equalled or exceeded annual rental due under lease;

5 years, if no production but discovery has been made or is deemed imminent;

maximum of $\mathbf{5 0}$ years from lease date

(no lease terms established)

5 years

10 years

10 years

for duration of commercial production; or 1-year terms, in absence of production, upon payment of s5/acre advance royalty

so long as drilling with diligence; or upon commercial discovery, up to 20 years

so long as geothermal resources produced or capable of being produced in commercial quantities 10-year intervals, beginning 20 years after lease date

\section{3-year intervals}

10-year intervals 
variable; syacre minimum

sot Iess than $\$ 1 / 3 c$ :e

Stacre

S1/acse

5tzre: as btd or ser in lease

surface occupant: as agreed or set by Board of Land and

Natural Resources

first 5 years: $\quad \$ 1 / a c r$

second 5 years: $\$ 2 / a c r e$

thereafter. \$3/acre

at least \$1/acre or $4 / 2$ cash bonus,

whichever is greater

at least Suacre

SWacre

suacre

S5/acre for lesses extended for sscond

joyear term without production

$\begin{array}{ll}\text { years 1-3: - - } & \text { SIacre } \\ \text { year 4: } & \text { s3lacre } \\ \text { years 5-10: } & \text { s5lacre } \\ \text { years renewed: } & \text { S5lacre }\end{array}$

(no lease terris established)

SHacre

primary: $\quad 10 \%$

byproduct $10 \%$ (net proceeds)

primary: $10 \%$

it least SUacre;

at least S5iacre upon commercial

production

S2aare
Royalties

$\begin{array}{lc}\text { primary: } & 10-15 \% \\ \text { byproduct: } & 2-10 \% \\ \text { minimum: } & \text { s2/acrejyear }\end{array}$

primary: at least $12.5 \%$

byproduct: at least $12.5 \%$

shut-in: 4 times annual rental

per yeas

primary: $\quad 10 \%$

byproduct: between $2 \%$ and $10 \%$

minimum: S2Jacrelyear

$\begin{array}{lc}\text { primary: } & 10 \% \\ \text { byproduce: } & 5 \% \\ & \\ \text { prdmary: } & 10 \% 20 \% \\ \text { byproduce: } & 5-10 \%\end{array}$

primary: $\quad 10 \%$

byproduct: $\quad 5 \%$

primary: at least $10 \%$

byproduct: at least $5 \%$

primary: at least $10 \%$

byproduct between $2 \%$ and $5 \%$

shut-in: set in lease

minimum: S2lacrejyear

primary: $\quad 12.5 \%$

byproduct: $5.0 \%$

primary: 10\%-15\% (KGRA)

byproduct between $2 \%$ and $10 \%$

recreation or

therapeutic: between $2 \%$ and $10 \%$

powerplant: $8 \%$ (nef revenue)

minimum: S2/acrejyear

primary: $\quad 10 \%$

byproduce $1 \%$, denineralized water

$5 \%$, other

(rentals paid each year deducted from royalties due
Acreage Limit

minimum lease: 640 acres

maximum lease: 2,560 acres $(5,750$ for submerged lands)

maximum state holdings: 25,600 acres

maximum lease: 2.560 acres (4 sections) cortined to 6 miles square

minimum lease: $\quad 640$ acres

maximum lease: $\quad 2,560$ acres

maximum state holdings: 25,600 acres

(includes acreage under exploration permit)

ginimu lease: 100 acres

maximum lase: 5,000 acres, of

2,300 if length of trace is

gore chan six times whe rdith

paximm scace holding: 90,000 us-

jeveloped acres

minimu lense: all state lanos within : section must de leased

maximum iease: 640 scres

maximum state holdings: incerest in 50

cownsnip-andoranges

maximum lease: 5000 acres

maximum lease: $\quad 640$ acres

minimum lease: $\quad 640$ acres

maximum lease: - 2,560 acres

maximum state holdings: 5?,200 dores

minimum lease: $\quad 40$ acres

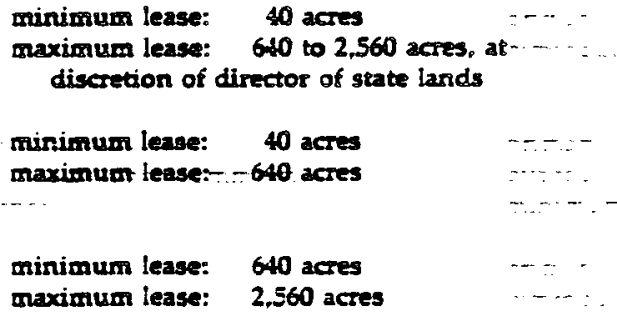


$\begin{array}{ccc}\text { State } & \text { Non-RGRA Lands } & \text { Subsequent } \\ \text { Leasing }\end{array}$

Alaska

Arizona

Competitive

$-\infty$

(A)

Competitive

(B)

Hawa1i

Idaho

Public Drawing (30-day filing)

Louisiana

(C)

Montana

Competitive

(C)

Nerada

New Mexico

Oregon

Texas

Utah

Wastington
Competitive (30 day filing)

Public Drawing (30-day filing)

(C)

Cash Bonus (E)

(15-day filing)

Compet1tive
(A)

Competitive

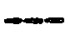

Competitive (B)

By Application

(C)

Competitive

(C)

By Application

By Application

(C)

By Application

Competitive

Cash Bonus (F) or other

(A)

(A)

(C)

Cash

Bonus (D)

(C)

(E)
KGRA Lands (Competitive Leasing) BIdding

Designation Factor

(A)

(A)

Cash Bonus

A11 lands awarded competitively

Cash Bonus

Producing Well

(A)

Cash Bonus

Cash Bonus

(A)
(C)

(E)

A11 lands awarded competitively (B)

Producing Well

All lands awarded competitively

(C)

Determined by Commissioner of Lands

Geology and/or producing wel1

All lands awarded competitively

Wyoming

$-\infty$

(A) Specifled by state land commisstoners

(B) Mineral reserve lands may be leased non-competitively to occupier (or assignee) with two-thirds vote by Board of Land and Natural Resources.

(C) Regulations not Elnalized

(D) If no bids received, Division of State Lands may reclassify for non-competitive leasing

(E) Lands are offered non-competitively by order of application, except when they are newly offered. Newly offered lands are leased by cash bonus bidding.

(F) Unlike Montana, if a tract receives no bid, it is withdrawn.

STATE GEOTHERMAL LEASE TERMS 
AHPENULX 5

ENACTED INCENTIVES FOR GEOTHERMAI DEVELORMENT

INCOME TAX

Colorado

H.B. 1019 (1978)

Commercial or residential

investments for solar, wind and geothermal energy systems deductible for state income tax.

S.B. 321 (1979)

Include geothermal system is alternative energy devices for income tas deduction.

Icaho.

B.B. 468

Income tas deduction for investments in residential geothermal energy facilities.

Montana

B.8. 292

Tax deduction for residential nonfossil energy generating systems (may apply to geothermal).

S.B. 167 (1977)

Oregon

S.B. 399

PROPERTY TAX

Colorado

S.B. 316

(1979)

Mawai:

S.B. 2467

(1976)

Mevada
A.B. 144

(1979)

A.B. 277

(1977)

South Dakota

E.B. 1354
Tax credit for nonfossil energy systems (may apply to geothermal).

Income tax credit up to $\$ 1 ; 000$-for residential geothermal space heat ing.

Exclude alternative energy devices from valuation of property for property tax assessment.

Property tax exemption for building. improvements to use geothermal esergy.

Exempt nonproducing geothermal leases from property tax.

Property tax credit up to $\$ 2,000$ for residential geothermal facilities for heating and cooling.

Residential and commercial property. tax credit for geothermal and other renewable energy systems. 
Enacted Incentives for Geothermal Development Page Two

\section{SAIES TAX}

Hawaii

B.B. 3033

(1978)

IOANS

$\begin{array}{ll}\text { Alaska } & \begin{array}{l}\text { B.B. } 266 \\ \text { Ch. } 29\end{array} \\ \text { Oregon } & \text { S.B. } 477 \\ \text { Virginia } \quad \text { H.B. } 100 \\ \text { Ch. } 631\end{array}$

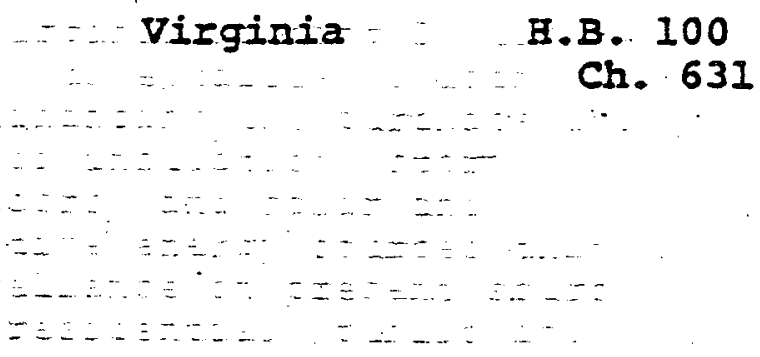

IEASING POIICY

CaIifornia

$$
\text { S.B. } 1027 \text { (1978) }
$$

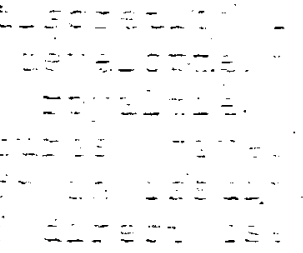

\section{New Mexico}

H.B. 446

(1979)
Determines the applicability of excise taxes on geothermal gross proceeds. Provides for royalties in lieu of a severance tax. Clarifies utility access.

Establishes an alternative power resources revolving loan fund within the state Department of Commerce and Economic Development.

Loan program for veterans-ap to $\$ 3,000$ for Iesidential geothermal energy facilities.

Directs the Virginia Housing Development Authority to establish a loan program for financing the purchase and installation of insulation, storm windows and doors, and solar and other alternative energy sources that will reduce reliance on present sources of energy in residential, public and nonprofit buildings.

Modifies leasing procedures giving State Lands Commission discretion in issuing exploration and development leases; revises rentals, royalties and renegotiation procedures; gives the commission discretion in issuing and setting the terms of direct use leases.

Extend the acreage 1imitation on state geothermal leases from 25,000 to 51,200 acres and provide for a second 5-year lease tern without production upon payment of increased rental. 
Enacted Incentives for Geothermal Development Page Three

DEVELOPMENT REGUIATIONS

California

A.B. 2644 (1978)

Streamines geothermal exploration and field development regulation and facility siting; authorizes the state energy commission to prohibit curtailment of geothermal power production or transmission.

Oregon . B. B. 2159 (1979)

H.B.2134 (1979)

Authorizes waiver of state bording requirements for well drilling if operation has bond with federal goverment.

Establish procedures for reinjecting geothermal fluids and permit DOGAMI to adopt regulations on reinjection and require DEO water pollution control facilities permit for reinjecting contaminated fluid.

\section{UTILITY REGULATIONS}

Califorria $\quad$ S.B. 77

A.B. 2644

(1978)

A.B. 4032 (1976)

Hawai :

S.B. 995

(1976)
Expowers RUC to order public utilities to transmit electricity generated by private producers from non-conventional sources.

Streamilnes geothermal exploration and field development regulation and facility siting; authorizes the state energy commission to grohibit curtailo ment of geothermal power production or transmission.

Higher rate of return allowed-fó utility investments in renewable energy facilities.

Exempts nonfossil power generation and transmission facilities from PUC regulation when energy used by producer or sold directly to public utility. Authorizes PUC to require public utilities to purchase surplus power from such facilities. 
Enacted Incentives for Geothermal Development Page Four

Utility Regulations cont.

Bawaii B.B. 2165 (1978)

H.B. 3033 (1978)

Ransas

E.B. 2842 (I978)
Makes rates paid by public utilities to geothermal developers for geothermal steam, or electricity Erom geothermal steam, subject to PUC regulation.

Determines the applicability of excise taxes on geothermal gross proceeds. Provides for royalties in lieu of a severance tax. Clarifies utility access.

Allows utilities to receive a $1 / 28$ to 28 higher rate of return on investments in systems which derive energy from solar, geothermal and other renewable energy sources.

Authorizes counties individually or together with utilities and end users to develop geothermal and other alternative energy resources.

Energy Conservation and Production Fund financed by state bond issues established to assist utility companies and individuals in development of non-nuclear energy resources. Emphasis on gecthermal and other resources not currently in widespread use. Oregon Department of Energy authorized to develop alternate. energy projects, fix rates and sell energy.

SJR 32

(1977)

Authorizes issuance of bonds for Energy Conservation and Production Fund (rejected by voters).

B.B. 3185 (1975)
Authorizes geothermal heating districts with contracting and bonding authority and power of eminent comain. 
Enacted Incentives for Geothermal Development

Page Five

Development Authorizations cont.

Oregon

S.B. 502

(1979)

Permit joint participation in geothermal activities of cities and people's utility districts in Oregon with cities, utility districts, electric cooperatives and privately owned electric utility companies in Nevada and California.

IIFE-CYCLE COSTING/BUIIDING CODES

Mafyland E.B. 413 (1978)

Requires consideration of Iife-cycle costing and energy consumption analyo sis during the preliminary design of new buildings financed by the state or with state assistance.

Mississippi S.B. 2379 (1978)

Establishes Iife-cycle costing in the design of state buildings.

Nevada

5.B. 326

(1977)

State energy conservation standards for buildings must allow design and construction latitude to the extent that solar, geothemal, of other nondegletable energy sources are used.

New Jersey A.B. 562 (1978)

Requires life-cyele cost aralysis in the design phase of any construction or renovation of major facilities.

The analysis must compare alternative energy systems.

New Mexico

8.8. 395

(1975)

Iife-cycle cost analysis of nonfossil energy systems required. for new state buildings or major renovations.

Ohio

E.B. 419 (1978)

Reguires life-cycle cost analysis in state-owned, assisted or leased facilities.

Texas

ESR 24

(1977)

Requests all state agencies and universities to excourage feasibility studies and demonstration projects for alternate energy use is state buildings. 
Enacted Incentives for Geothermal Development Page Six

OMBUDSMAN/TECENICAI ASSISTANCE

Oregon $\quad$ S.B. 572 (1977)

Energy Conservation and Production Fund financed by state bond issues established to assist utility companies and individuals in development of nonnuclear energy resources. Emphasis on geothermal and other resources not currently in widespread use. Oregon Department of Energy authorized to develop alternate energy projects, fix rates and sell energy.

RESEARCH AND DEVELOPMENT/DEMONSTRATIONS

Arizona

B.B. 2078 (1979)

Hawai $i$

S.B. 1581

H.B.० 3039

घ.B. 1680 (1979)

Montana

S.B. 86

New Mexico

S.B. 185

(1975)

E.B. 199

(1978)

H.B. 2

OWNERSHIP

Washington

S.B. 2191

(1979)
Expands activities of Arizona solar Energy Research Commission to include other renewable energy sources, incluain geothermal.

Major funding provided for geothermal resource assessment; research and development of non-electric uses; and the rift zone laboratory.

Establish the Energy Laboratory of Hawaii and make appropriations.

Applies state coal tax fund to renewable energy projects.

Created permanent fund for energy research and development and appropriated funds.

$\$ 2$ million appropriation for energy research and development.

$\$ 200,000$ appropriation for establish ing geothermal space heating demonstration projects. I00\% matching funds required.

Place ownership of geothermal resources with the surface owner (private). 

Geothermal Policy Project.

\section{ABSTRACT}

District heating is a proven vehicle for the direct application of geothermal energy. Successful systems currently exist in Iceland, France and the U.S., with numerous others in planning or construction stages. As geothermal resources come on-line, district heating is likely to be a widespread method of utilization. Such systems will provide centralized space-conditioning, as well as "cascaded" uses where feasible. Legal and institutional factors should be examined to ensure an adequate foundation for implementing geothermal district heating.

\section{INTRODUCTION}

District heating basically means the centralized distribution of heat to multiple endusers within a particular service area. Cascaded utilization would involve the successive use of progressively cooler fluid (e.g. industrial process heat, space-conditioning, greenhousing, aquaculture). The heat source may be geothermal, solar or fossil fuel. The use of cogenerated or waste heat would be especially appropriate. If al ternate energy sources are used, supplemental fossil fuel capacity may be necessary to meet peak demands or emergencies. Various entities, both private and public, may constitute Yahicles to develop and operate a heating district. Such a heating district will be presumed to be a utility.

\section{INVESTOR-OWNED UTILITIES}

The private sector may organize a heating district by incorporating an investor-owned utility. Some existing utilities may already have a steam distribution system in place. In other states, specific legislative authorization for utilities to provide district heating services may be required. Such authorization should allow the production and transmission of various heat mediums, including geothermal, for public and private use.

In order to incorporate a new investor-owned utility, or expand the scope of an existing one, certification from the Public Service Commission (PSC) will ordinarily be necessary. Such a "certificate of public convenience and necessity" may be difficult to obtain where the heating district would impinge on an existing heating utility (gas/electric) service area. State legislatures should consider exempting heating districts using alternate fuel sources or waste heat from the certification requirement. Al ternatively, they may direct the PSC to grant certification where the public interest would be served, despite competition with an existing utility.

Investor-owned utilities are under the ratemaking jurisdiction of Public Service Commissions, al though this may not be clear where heating/ cooling services are newly authorized. PSC control of utility rates normally is justified due to the monopoly status accorded a utility in a particular service area. State legislatures may consider, as an incentive to investment, exempting heating districts using alternate or waste heat sources from PSC rate-making jurisdiction.

Thus, legislatures should review at least three aspects of district heating via investor-owned utilities: the authorization to provide district heating services; the requirement of PSC cerification; and, the applicability of PSC rate-making jurisdiction.

\section{PUBLICLY-OWNED UTILITIES}

Counties, municipalities, special districts and other political subdivisions also are possible vehicles for implementing district heating. However, most political subdivisions possess no inherent powers. Thus, specific enabling legis. lation often will be necessary to authorize a political subdivision to organize a heating district. In some cases, municipal utility codes or authorizations to provide "water" may be liberally construed to cover district heating services. "Home rule" entities also may be able to implement district heating on their own initiative.

Where new enabling legislation is required, at least two approaches are possible. One is to enact a comprehensive, specific statute such as Oregon's Geothermal Heating Districts Act (ORS Chap. 523, 1977). Such an approach has the advantage of authorizing entities with a specific, single mandate. Alternatively, an existing political subdivision charter may be amended to include district heating, as Idaho has done with 
its municipal code (S. 1062, 1979). While the district heating mandate to such entities may be diluted by existing functions, this approach has the advantage of utilizing personnel and infrastructure in place. In addition, where existing bonding and other powers are already adequate, the legislative drafting job is simplified.

Special districts, a species of local government, offer several advantages as district heating vehicles. They may usually cross other political subdivision boundaries and may sometimes include non-contiguous areas, important factors in matching resource and service load centers. Special districts may be able to impose differential taxing coincident with service areas. Their bond issues normally are exempt from constitutional debt limitations applied to cities and counties. And, they are organized and operated to perform a narrow range of similar functions.

Whatever political subdivision is chosen as a district heating vehicle, certain basic parameters need to be established. These relate to the method of heating district formation, the nature of its boundaries, its purposes and $i$ ts powers, especially financial.

Formation of a heating district will normally involve resolutions of the governing bodies of participating political subdivisions or, perhaps, a local citizen initiative. A referendum on the matter may be required, especially where the district would have property taxation (ad valorem/special assessment) power. State Tegislative and/or Public Service Comission approval also may be necessary, al though this is less common.

A heating district should have flexibility with regard to its boundaries. The crossing of municipal and county lines, and the inclusion of non-contiguous areas, may be necessary to match the heat source with load centers. Annexation capability would be a useful adjunct. The district also may require extra-territorial jurisdiction over sources of supply and facilities.

The purposes of a heating district will generally be to produce, distribute, utilize, sell and dispose of geothermal resources and other heat mediums for domestic, commercial and industrial use. The authority should be broad enough to include geothermal and cogenerated or waste heat sources, as well as the use of fossi] fuels for peaking or emergencies such as well shut-downs. While centralized spaceconditioning may often be the primary function, integrated development of cascaded uses should be within the purview of the district.

Since political subdivisions are inherently not risk-taking entities, the exploration function may require an innovative approach. Exploration may be an appropriate function for the district where the geothermal resource is demonstrated or where outside (state/federal) capital is available. Otherwise, joint enterprise ability - joint power authorities (with other political subdivi sions) and joint ventures (with private industry) - may be necessary to obtain financing. Alternatively, franchises may be granted to private companies to explore for and produce the resource under a contract of sale. Exemption of such production from PSC rate-making jurisdiction would be an appropriate incentive to attract private risk capital. Publicly-owned utilities already are exempt from PSC jurisdiction in most states.

A geothermal heating utility will require the range of powers of a body corporate and politic: legal status to sue and be sued; ability to contract for services and employ personne?; ability to acquire and dispose of property (within and without the district); ability to fix rates for service; ability to apportion user charges and enforce collection (usually via liens); and, the ability to generate capital.

The most likely avenue for capital financing of a geothermal heating district will be revenue bond issues. Service charges would be designed, and may be statutorily required, to retire revenue bond princjpal and interest, as well as covering operating expenses. However, the ability to levy special assessments may be a necessary concomitant in order to cover revenue shortfalls. Revenue bond issues are not subject to constitutional debt limits and usually need not be approved in an election.

Where the district has ad valorem taxation power, it may be authorized to issue general obligation bonds. Such bonds also may be retired by project revenues but are supported by the full faith and credit (taxes) of the issuing district. General obligation bonds will usually be subject to debt limits if the issuing authority is a municipality or county. Debt limits for special districts are less common, and if applicable, special district debts are generally not cumulative with other local political subdivision debt. General obligation bond issues may need to be approved in an election.

Whatever the bond option chosen, marketability is subject to legislative initiative. State legislatures should consider declaring heating district bonds a legal investment for all banks, trust funds, school funds and other institutional investors. Such accreditation would expand the capital market for the bonds.

A final consideration regarding the powers of heating districts is the grant of easements and eminent domain. Easements along, across and under public byways and existing transmission corridors would assist the district in forming $i$ ts distribution network. The power to condemn easements on certain private property also may be necessary to complete the system. Consideration may be given to extending the eminent 
domain power to existing geothermal wells and sources of supply, al though such a proposal is likely to be controversial.

The problem of condemning existing wells or their forced incorporation into a heating district may be unavoidable where single or multifamily wells are already in use. Geothermal production for a heating district may result in reservoir drawdowns, rendering such wells useless. District monetary liability for such events, as opposed to the issuance of an injunction restraining operations, would result, as a practical matter, in condemnation. A possible method to minimize such liability would be the designation of system-wide economic drilling levels, above which no liability would accrue to the district.

Thus, the legislative agenda for public district heating is manifest. The charters of existing political subdivisions should be examined to identify suitable candidates and amended as necessary. Alternatively, a comprehensive, new district heating statute may be enacted. Formation, boundaries, purposes and powers are the parameters which need to be established for public heating districts.

\section{CONCLUSION}

While this paper has focused on the specific legal and institutional parameters of geothermal district heating, there are additional factors subject to legislative initiative which will generally affect the pace of implementing such systems. These include: public funding for demonstration projects; geoheating public buildings: innovative and compatible building codes and zoning ordinances; public education and technical assistance; loan programs and tax incentives for al ternate energy systems; royalties and taxes on resource production; streamlined regulatory and leasing procedures; and, resolution of ownership and water rights issues. While beyond the scope of this paper, the NCSL geothermal project is prepared to assist states to deal with these policy areas. 